*alls View/Frint Document Cover Sheet tose

This document was retrieved from the Boeing ISEARCH System.

Accession \#: D196069872

Document \#: SD-WM-TP-341

Title/Desc:

TANK 241BX112 TANK CHARACTERIZATION PLAN 


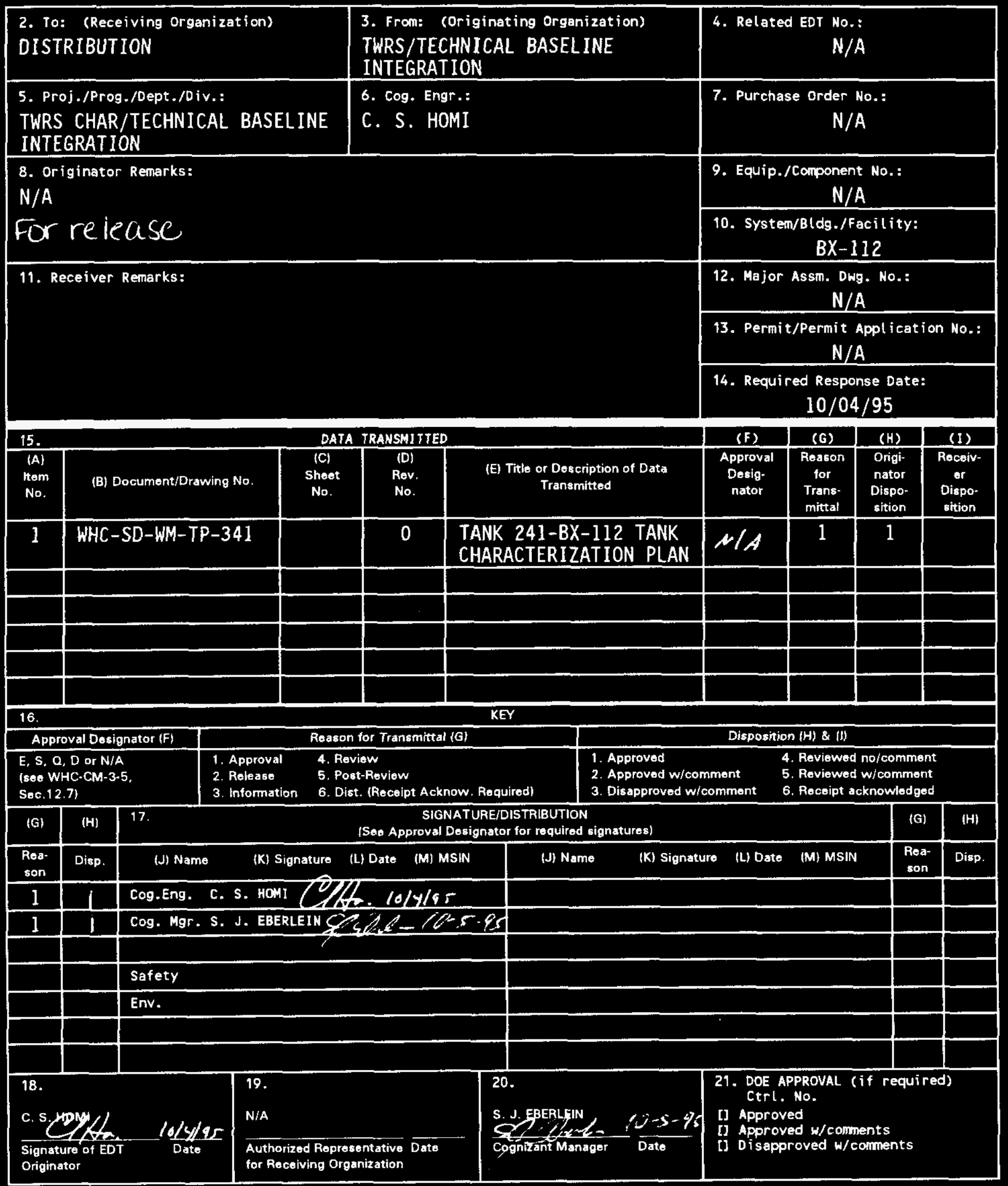




\section{RELEASE AUTHORIZATION}

Document Number: WHC-SD-WM-TP-341, REV 0

Document Title: ' Tank 241-BX-112 Tank Characterization Plan

Release Date: $\quad 10 / 19 / 95$

This document was reviewed following the procedures described in WHC-CM-3-4 and is:

APPROVED FOR PUBLIC RELEASE

WHC Information Release Administration Specialist:
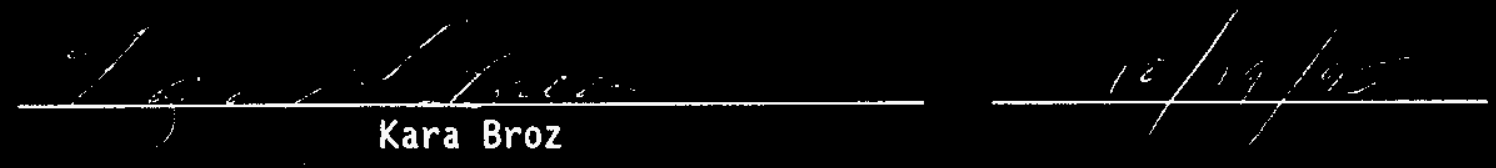

TRADEMARK DISCLAIMER. Reference here in to any specific commercial product, process, or service by trade name, trademark, manufacturer, or otherwise, does not necessarily constitute or imply its endorsement, recommendation, or favoring by the United States Government or any agency thereof or its contractors or subcontractors.

This report has been reproduced from the best available copy. Available in paper copy. Printed in the United States of America. To obtain copies of this report, contact:

Westinghouse Hanford Company - Document Control Services

P.0. Box 1970, Mailstop H6-08, Richland, WA 99352

Telephone: (509) 372-2420; Fax: (509) 376-4989 


\section{SUPPORTING DOCUMENT}

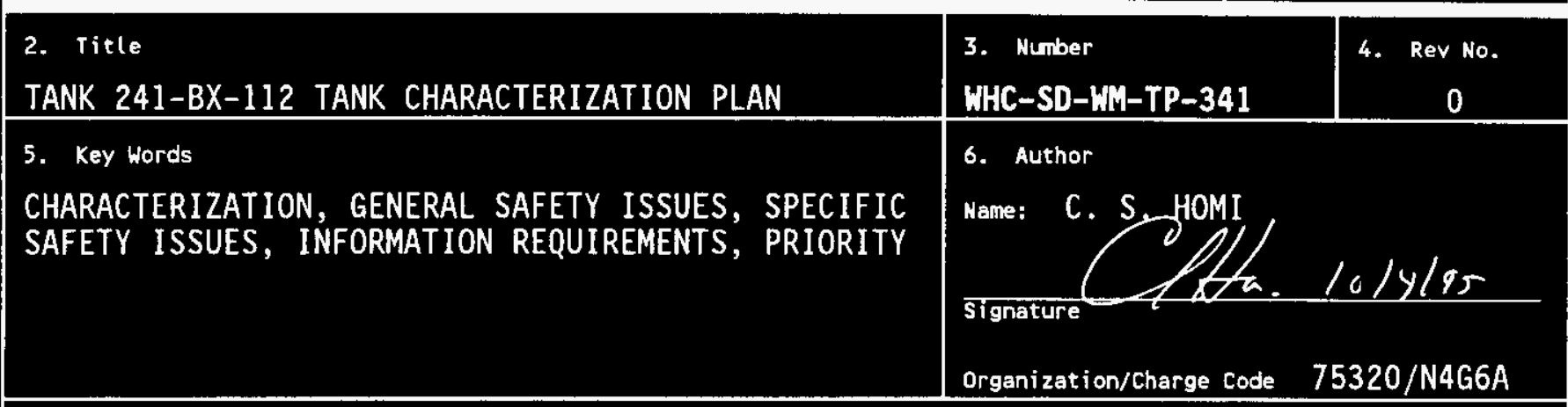

\section{Abstract}

This document is a plan that identifies the information needed to address relevant issues concerning short-term and long-term safe storage and long-term management of Single-She11 Tank (SST) 241-BX-112.
8.

RELEASE STAMP

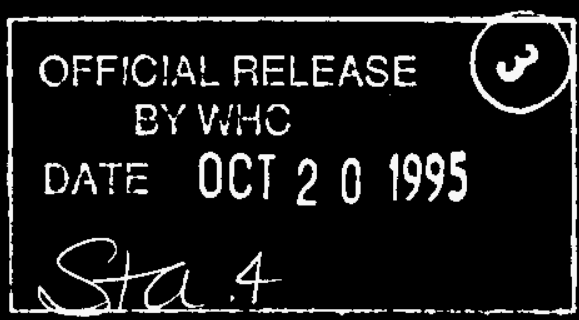


WHC-SD-WM-TP-341

Revision 0

UC-2070

\title{
Tank 241-BX-112 \\ Tank Characterization Plan
}

\author{
C. S. Homi \\ Westinghouse Hanford Company
}

\section{Date Published \\ October 1995}

Prepared for the U.S. Department of Energy

Office of Environmental Restoration and

Waste Management

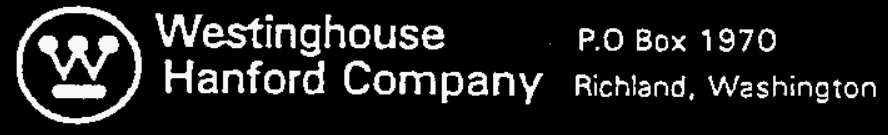

Management and Operations Contractor for the

U.S. Department of Energy under Contrect DE.AC06.87FL 10930 


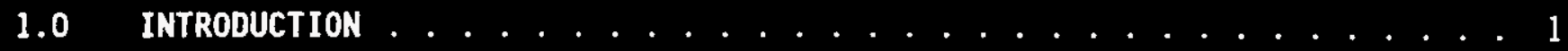

2.0 PROGRAM ELEMENTS REQUIRING INFORMATION FOR 241-BX-112 ........ 2

2.1 geNERAL SAFETY ISSUES .................. 2

2.2 SPECIFIC SAFETY ISSUES .................. 2

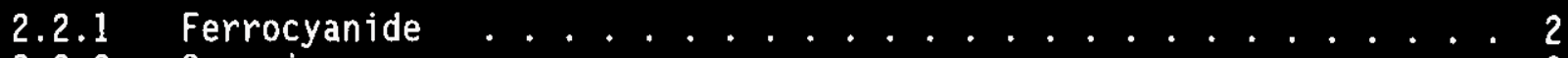

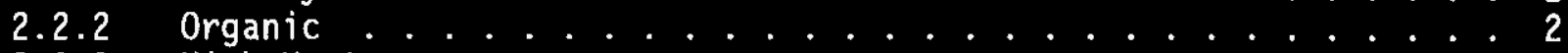

2.2 .3 High Heat ................. 2

2.2 .4 Flammable Gas ................... 2

2.2 .5 Vapor ........................ 2

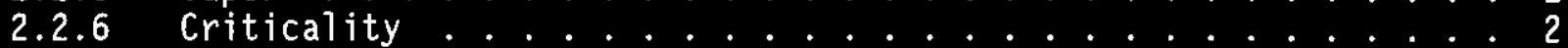

2.2.7 Screening Approach Evaluation ............. 3

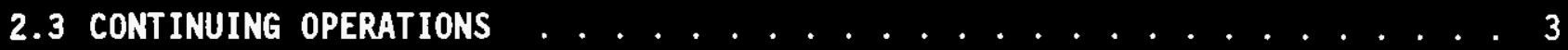

2.2.1 Compatibility/Stabilization ............ 3

2.2 .2 Evaporator .................. 3

2.4 DOUBLE-SHELL TANK WASTE ANALYSIS PLAN . . . . . . . . . . . 3

2.5 DISPOSAL . . . . . . . . . . . . . . . 3

2.5.1 Retrieval ............. 3

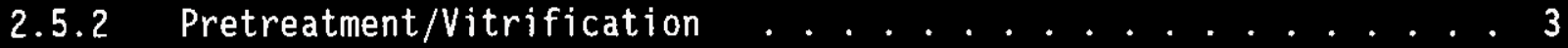

2.6 HISTORICAL MODEL EVALUATION . . . . . . . . . . . . 3

3.0 HON INFORMATION WILL BE OBTAINED ................ 4

4.0 PRIORITY OF INFORMATION REQUIREMENTS ............. 5

5.0 WHEN INFORMATION IS NEEDED ................ 5

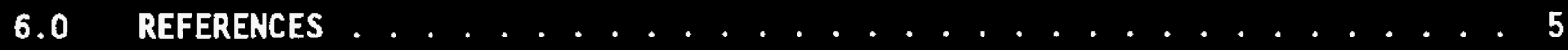

\section{LIST OF TABLES}

Table 4-1: Integrated DQO Requirements ............ 5 
WHC-SD-WM-TP-341, REV 0

LIST OF ABBREVIATIONS

$\begin{array}{ll}\text { BX-112 } & \text { Tank 241-BX-112 } \\ \text { DQO } & \text { Data Quality Objective } \\ \text { HTCE } & \text { Historical Tank Content Est imate } \\ \text { DSSF } & \text { Double She11 Slurry Feed } \\ \text { NCPLX } & \text { Non-complexed } \\ \text { SST } & \text { Single-She11 Tank } \\ \text { TCP } & \text { Tank Characterization Plan } \\ \text { TOC } & \text { Total Organic Carbon } \\ \text { USQ } & \text { Unreviewed Safety Question } \\ \text { WHC } & \text { Westinghouse Hanford Company }\end{array}$




\section{WHC-SD-WH-TP-341, REV 0}

\subsection{INTRODUCTION}

This Tank Characterization Plan (TCP) identifies the information needed to address relevant issues concerning short-term and long-term safe storage and long-term management of Single-She11 Tank 241-BX-112 (BX-112). It should be understood that the various needs and issues surrounding tank BX-112 are evolving as new information about the tank is uncovered. As a result of this progression, this Tank Characterization Plan addresses only the issues that, to this date, have been identified. It is expected that deviations from this plan may occur as additional issues or needs arise which impact the management of SST BX-112. As necessary, this Tank Characterization Plan will be revised to reflect those changes or deviations.

Tank BX-112 was constructed between 1946 and 1947 and was put into service in 1951 . Initially tank BX-112 was filled with first cycle waste during the third and fourth quarters of 1951. Between the second quarter of 1952 and the second quarter of 1954, the tank contained first cycle waste. During the fourth quarter of 1953, the supernatant was pumped to a ditch. The tank contained first cycle waste and evaporator bottoms from the third quarter of 1954 to the second quarter of 1964 . The tank was declared a spare for U plant scavenged waste in 1954. From the second quarter of 1965 until the second quarter of 1968, the tank received first cycle evaporator bottoms waste and coating waste. Also, during the first quarter of 1968, the tank received wastewater. From the third quarter of 1968 until the second quarter of 1976, the tank contained evaporator bottoms waste and ion exchange waste. The tank contained dilute evaporator feed from the third quarter of 1976 until the fourth quarter of 1977. Presently, the tank waste is classified as non-complexed. This tank currently contains waste with a total waste volume of $624.6 \mathrm{~kL}$ (165 kgal), which is equivalent to 141.2 centimeters ( 55.6 inches) of waste as measured from the baseline of the tank. The waste is comprised of $3.8 \mathrm{~kL}(1 \mathrm{kgal})$ of supernatant; $499.7 \mathrm{~kL}$ (132 kgal) of sludge and $121.1 \mathrm{~kL}(32 \mathrm{kgal})$ of unknown waste with $7.6 \mathrm{~kL}$ (2 kgal) pumpable liquid remaining (Brevick 1994a).

The tank is sound and was declared inactive 1977. Tank BX-112 is passively ventilated and interim stabilized in September 1980 with partial isolation completed. The last photo was taken on September 11, 1990. The 1990 photographic montage of the tank interior indicates a brown or gray solid waste intermixed with pools of dark yellow translucent liquid (Brevick 1994b). The last solids volume update was obtained on September 17, 1990 (Hanton 1995).

A composite sample made up from Tank 241-BX-112 made up of three core segments was analyzed in August 1979. The sample was 1 ight yellow sludge with a consistency of soft putty. The sludge solids were $24 \%$ water soluble. The primary components of the waster soluble portion were sodium, nitrate and phosphate. The water insoluble portion consisted of aluminum, bismuth, nitrate, phosphate and silicon. Also, in 1980 another tank sample was analyzed to evaluate laboratory methods.

This tank is not on any Watch list. Near-term sampling and analys is activities are focused on either verification of the non-watch 1 ist tank status, identification of any new safety issues or changing the non-Watch List status. Should any safety issues be identified additional analysis will occur consistent with the identified issue.

In addition to the resolution of the safety issues, it is intended that all tank waste will be subject to pretreatment and retrieval to prepare for final storage or disposal. Presently, these long-range plans have yet to be fully identified and are, therefore, not included in this document. 
WHC-SD-WM-TP-341, REV 0

\subsection{PROGRAM ELEMENTS REQUIRING INFORMATION FOR TANK 241-BX-112}

This section identifies the various program elements, and identifies which of these programs require characterization data from tank $\mathrm{BX}-112$.

\subsection{GENERAL SAFETY ISSUES}

The Tank Safety Screening Data Quality Objective (Dukelow et al. 1995) describes the sampling and analytical requirements that are used to screen waste tanks for unidentified safety issues. The primary analytical requirements for the safety screening of a tank are energetics, total alpha activity, and flammable gas concentration. Moisture determination is also needed to make correction to the total fuel dry basis criteria.

\subsection{SPECIFIC SAFETY ISSUES}

\subsubsection{Ferrocyanide}

This tank is not on the Ferrocyanide Watch List and; therefore, no information needs are currently identified for this program element.

\subsubsection{Organic}

Tank BX-112 is not on the Organics Watch List and; therefore, no information needs are currently identified for this program element.

\subsubsection{High Heat}

This tank is not on the High Heat Watch List and; therefore, no information needs are currently identified for this program element.

\subsubsection{Flammable Gas}

This tank is not on the Flammable Gas Watch List and does not contain enough waste (Barton, 1995) to come under the trapped gas barometric fluctuation criteria (Whitney, 1995).

\subsubsection{Vapor}

The tanks currently scheduled to be vapor sampled may be classified into four categories: (1) those tanks which are to be rotary mode core sampled (as a consequence of the rotary sampling system); (2) tanks on the Organic or Ferrocyanide Watch Lists; (3) tanks in C farm; and (4) tank BX-104, due to vapor exposure. Since tank BX-112 is not categorized in one of the above four groups, vapor sampling is not required for this tank.

\subsubsection{Criticality}

No information separate from that for the general safety issue of tank BX-112 are currently identified for this program element. However, if the general safety screening of tank $B X-112$ identifies a potential criticality concern, analyses for fissile materials and neutron absorbers and poisons will be performed as identified in the safety screening data quality objective. 


\subsubsection{Screening Approach Evaluation}

The safety screening approach is currently under review. Information is required from key tanks to determine if a revised approach to screening may be adopted, as proposed in Meacham, 1995.

\subsection{CONTINUING OPERATIONS}

\subsubsection{Compatibility/Stabilization}

No information needs are currently identified for this program element.

\subsubsection{Evaporator}

No information needs are currently identified for this program element.

\subsection{DOUBLE-SHELL TANK WASTE ANALYSIS PLAN}

This section does not apply because tank $B X-112$ is a single shell tank.

\subsection{DISPOSAL}

\subsubsection{Retrieval}

Current retrieval needs (Bloom 1995) do not call for test samples to be taken from tank BX-112.

\subsubsection{Pretreatment/Vitrification}

Tank BX-112 has not been identified as a bounding tank for pretreatment/disposal process development (Kupfer 1995).

\subsection{HISTORICAL MODEL EVALUATION}

Bounding tanks and data requirements for historical model evaluations are found in DQ0 Historical Model Evaluation Data Requirements (Simpson 1995). Tank BX-112 has been identified as an alternative priority 3 bounding tank for the $1 \mathrm{C}$ (first cycle decontamination waste from the bismuth phosphate process) waste type but will not be assessed against the historical DQO unless directed by the program. 


\subsection{HOW INFORMATION WILL BE OBTAINED}

The safety screening $D Q 0$ requires that a vertical profile of the tank waste be obtained from at least two widely spaced risers. This vertical profile may be obtained using core, auger (for shallow tanks), or grab samples. Both auger and push mode sampling events are scheduled. No other sampling is scheduled through fiscal year 1997 (Stanton 1995). Auger crust samples will be taken for preliminary safety screening and the push mode sampling will be taken later to complete the requirements of safety screening.

The best current estimate of the water content in tank BX-112 solids, as determined from the process records, is $66.7 \%$; based on the HTCE (Brevick 1994a). Est imated (Toth et al 1995) water content in tank BX-112 sludge is $47.8 \%$ (generated from a model based on sample data from similar tanks). Moisture data will be used to correct the fuel waste dry basis and, if required, to resolve any safety issues. The TOC contained within the sludge is estimated (Toth et al 1995) to be $0.4 \%$ (wet basis), which is significantly lower than the level of concern. Two core samples will be requested for this tank. Should the measured mean be lower than anticipated or the measured variance higher, additional samples may be required.

It is recommended that available risers 2 and 3 be chosen because they are free of obstructions. Initial information will be taken from these 2 risers and assessed to determine if more samples are required. Alternate sampling methods, installation of a riser or removal of equipment from risers are possible future options. 
WHC-SD-WM-TP-341, REV 0

\subsection{PRIORITY OF INFORMATION REQUIREMENTS}

Vapor sampling is not required for this tank. Auger sampling is scheduled for November 1995. Push mode sampling is scheduled for March 1997 (Stanton 1995).

Table 4-1: Integrated DQO Requirements

\begin{tabular}{|l|l|l|l|}
\hline $\begin{array}{c}\text { Sampling } \\
\text { Event }\end{array}$ & \multicolumn{1}{|c|}{ Applicable DQO } & Sampling Requirements & Analytical Requirements \\
\hline Auger & -Safety Screening DQO & $\begin{array}{l}\text { Auger samples from 2 } \\
\text { risers }\end{array}$ & $\begin{array}{l}\text { Energetics, Moisture, } \\
\text { Total Alpha, SpG }\end{array}$ \\
\hline $\begin{array}{l}\text { Push Mode } \\
\text { Sampl ing }\end{array}$ & -Safety Screening DQO & $\begin{array}{l}\text { Core samples from 2 } \\
\text { risers separated to the } \\
\text { maximum extent possible }\end{array}$ & $\begin{array}{l}\text { Energetics, Moisture, } \\
\text { Total Alpha, SpG }\end{array}$ \\
\hline
\end{tabular}

\subsection{WHEN INFORMATION IS NEEDED}

Data are required for Tank BX-112 during FY 1996 for safety screening of the crust. A Tank Characterization Report will be written after the tank is push mode sampled in FY 1997.

\subsection{REFERENCES}

Barton, W. B., 1995, Flammable Gas Review of Non-Watch List Tanks, (internal memo 74A10-95-073, to distribution, October 17), Westinghouse Hanford Company, Richland, Washington.

Bloom, G. R., and Q. H. Nguyen, 1995, Characterization Data Needs for Development, Design, and Operation of Retrieval Equipment Developed Through the Data Quality Objective Process, WHC-SD-WM-DQO-008, Rev. 0, Westinghouse Hanford Company, Richland, Washington.

Brevick, C. H., 1994a, Historical Tank Content Estimate for the Northeast Quadrant of the Hanford 200 East Areas, WHC-SD-WM-ER-349, Rev. OA, ICF Kaiser Hanford Company, Richland, Washington.

Brevick, C. H., 1994b, Supporting Document for the Historical Tank Content Estimate for BX Tank Farm, WHC-SD-WM-ER-311, Rev. O, ICF Kaiser Hanford Company, Richland, Washington.

Brown, T. M., S. J. Eberlein, D. A. Dodd, T. J. Kunthara, B. C. Simpson, and N. W. Kirch, Tank Waste Characterization Plan and Basis, 1995, WHC-SD-WM-TA-164, Rev 0, Westinghouse Hanford Company, Richland, Washington. 


\section{WHC-SD-WM-TP-341, REV 0}

Dukelow, G. T., J. W. Hunt, H. Babad, and J. E. Meacham, 1995, Tank Safety Screening Data Quality objective, WHC-SD-WM-SP-004, Rev 2, Westinghouse Hanford Company, Richland, Washington.

Hanlon, B.M., 1995, Waste Tank Summary for Month Ending May, 1995, WHC-EP-0182-82, Westinghouse Hanford Company, Richland, Washington.

Homi, C. S., and S. J. Eberlein, 1995, Fiscal Year 1996 Tank Waste Remediation System Tank Waste Analysis Plan, WHC-SD-WM-PLN-101, Rev 0, Westinghouse Hanford Company, Richland, Washington

Kupfer, M. J., W. W. Schultz, and J. T. Slankas, 1995, Strategy for Sampling Hanford Site Tank Wastes for Development of Disposal Technology, WHC-SD-WM-TA-154, Rev. 1, Westinghouse Hanford Company, Richland, Washington.

McDuffie, N. G., 1995, Flammable Gas Tank Safety Program: Data Requirements for Core Sample Analysis Developed Through the Data Quality Objectives (DQO) Process, WHC-SDWM-DQ0-004, Rev. 1, Westinghouse Hanford Company, Richland, Washington

Meacham, J. E., R. J. Cash, B. A. Pulsipher, and G. Chen, 1995, Data Requirements for the Ferrocyanide Safety Issue Developed through the Data Quality Objectives Process, WHC-SD-WM-DQ0-007, Rev. 1, Westinghouse Hanford Company, Richland, Washington.

Osborne, J.W., J.L. Huckaby, E.R. Hewitt, C.M. Anderson, D.D. Mahlum, B.A. Pulsipher, and J.Y. Young, 1995, Data Quality Objectives for Generic In-Tank Health and Safety Vapor Issue Resolution, WHC-SD-WM-DQ0-002, Rev. 1, Westinghouse Hanford Company, Richland, Washington.

Price, D. N., 1994, Rotary Core Vapor Sampling Data Quality Objective, WHC-SD-WM-SP-003, Rev. 0, Westinghouse Hanford Company, Richland, Washington.

Simpson, B. C., and D. J. McCain, 1995, Historical Model Evaluation Data Requirements, WHC-SD-WM-DQO-018, Rev. 0, Westinghouse Hanford Company, Richland, Washington.

Stanton, G. A., 1995, Baseline Sampling Schedule, Revision 4.4, (internal memo 75610-95-01, to distribution, September 8), Westinghouse Hanford Company, Richland, Washington.

Toth, J. J., P. G. Heasler, M. E. Lerchen, J. G. Hill, and P. D. Whitney, 1995, Analysis of Organic Carbon and Moisture in Hanford Single-Shell Tank Waste, PNL10360, Pacific Northwest Laboratory, Richland, Washington.

Whitney, P. D., 1995, Screening the Hanford Tanks for Trapped Gas, (transmitted in letter WTSFG95 from J. W. Brothers to G. D. Johnson, West inghouse Hanford Company, April 28), Pacific Northwest Laboratory, Richland, Washington. 